\title{
Sokakta Çalışan Çocukların Yalnızlık ve Depresyon Düzeylerinin Ebeveyn Durumları Açısından İncelenmesi: İstanbul Örneği
}

\author{
Melda Meliha ERBAŞa, b, Tevfik Fikret KARAHANc, Tunahan UZUN ${ }^{\mathrm{d}}$
}

Özet

$\mathrm{Bu}$ çalışmanın amacı sokakta çalışan çocukların yalnızlık ve depresyon düzeylerinin çeşitli değişkenlere göre incelenmesidir. Çalışma grubunu İstanbul'da sokakta çalışan 651 çocuk oluşturmaktadır. Araştırmada değişkenleri ölçmek için "UCLA Yalnızlık Ölçeği" ve "Çocuklar İçin Depresyon Ölçeği" ve kişisel bilgi formu kullanılmıştır. Elde edilen bulgular, annesi hayatta olmayan ve üvey anneye sahip olan çocukların depresyon ve yalnızlık düzeylerinin diğerlerinden daha yüksek olduğunu göstermiştir. Bununla birlikte babası hayatta olmayan ve üvey babaya sahip olan çocukların depresyon düzeylerinin diğerlerinden daha yüksek olduğu saptanmıştır. Araştırmada ayrıca ebeveynleri birlikte olan çocukların depresyon ve yalnızlık düzeylerinin diğerlerine göre anlamlı derecede düşük olduğu ve sokakta çalışan çocuklarda yalnızlığın depresyon için anlamlı bir yordayıcı olduğu saptanmıştır. Elde edilen bulgular alan yazın ışığında tartışılmış, ruh sağlığı çalışanlarına ve ileride yapılacak araştırmalara yönelik önerilerde bulunulmuştur.
Anahtar Kelimeler

Çalışan Çocuklar

Yalnızlık

Depresyon

Üvey anne-baba

Makale Hakkında

Geliş Tarihi: 07.11.2019

Kabul Tarihi: 13.03.2020

Doi: $10.18026 /$ cbayarsos.643823

\section{The Depression and Loneliness Levels of the Children Working on the Street According to Their Parental Status: Istanbul Example}

\begin{abstract}
The aim of this study is to investigate the depression and loneliness levels of children working on the street according to some variables. The study group consisted of 651 children who were working on streets in İstanbul. Variables were measured by "UCLA Loneliness Scale", "Childhood Depression Inventory" and personal data form. Findings have been revealed, the depression and loneliness levels of children whose mother is death and has a stepmother were higher compared to others. The depression levels of children whose father is death and has a stepfather were higher compared to others. Also we have found that the children whose self-parents are together have lower levels of depression and loneliness, and loneliness is a significant variable for depression for children who works on the street. The findings are discussed and some recommendations are given for the psychiatric health professionals.
\end{abstract}

Keywords

Children Working on Street

Loneliness

Depression

Stepmother-father

About Article

Received: 07.11.2019

Accepted: 13.03 .2020

Doi: 10.18026/cbayarsos.643823

a melda.erbas@cbu.edu.tr

b Dr. Öğr. Üyesi, Manisa Celal Bayar Üniversitesi/Manisa ORCID 0000-0001-8640-5356

c Doç. Dr., Universidat Europea Madrid / Espana ORCID 0000-0002-1260-1239

d Uzman Psikolojik Danışman, Bafra İMKB Ortaokulu /Samsun ORCID 0000-0002-2512-6086 


\section{Giriş}

Çocuk işçiliği ve buna bağlı olarak sokakta çalışan çocuklar sorunu, dünyada genelinde görülen önemli toplumsal sorunların başında gelmektedir (Clark, 2011). Alan yazında sıklıkla karşılaşılan "sokak çocuğu" kavramının, "sokakta çalışan çocukları" çağrıştırması nedeniyle bu iki kavram arasındaki farkın ortaya konulmasının yararlı olabileceği düşünülmektedir. UNICEF'e (2007) göre sokak çocukları, yetişkin desteği ve gözetiminden yoksun olarak yaşamlarının tamamını sokakta sürdüren çocuklar olarak tanımlanmaktadır. Sokakta çalışan çocuklar ise harçlıklarını çıkarmak, okul giderlerini karşılamak, aile ekonomisine katkı sağlamak, bazen de tek başına aileyi geçindirmek için sokakta çalışan ancak akşam evine dönen çocuklardır. Sokakta çalışan çocukları sokak çocuklarından ayıran en belirgin fark ailenin çocuk üzerindeki denetiminin devam ediyor olmasıdır (Erdoğdu ve Erkan, 2006; Güneş ve Kalaycl, 2004). Sokakta çalışan çocukların büyük bir bölümü sokakta simit, su, mendil, çiçek vs. satan; tartıcılık ya da ayakkabı boyacılığı yapan, pazarda eşya taşıyan çocuklar olarak karşımıza çıkmaktadır (Alacahan, 2010; Durualp, 2007). Küçük yaşlardan itibaren sokakta çalışarak para kazanmaya başlayan ve göreceli olarak sokağın özgürlüğü ile tanışan bu çocuklar çoğunlukla aileleri ile yaşasalar da zamanla sokakta yaşamaya yönelebilmektedirler (Tuncel, 2003). Devlet İstatistik Enstitüsü'nün raporuna göre sadece İstanbul'da 625 bin çocuk sokağa yönelerek sokak çocuğu olma riski altındadır (Uluğtekin, 1997, akt. Güneş ve Kalayc1, 2004).

Hızlı nüfus artışı, göç, işsizlik, yoksulluk, kötü barınma şartları, aile içi şiddet, aile bütünlüğünün bozulması gibi faktörler aile bireylerinin yaşamını olumsuz etkilemektedir. Zorlaşan yaşam koşulları nedeniyle özellikle büyük kentlerde çalışan çocuk sayısı her geçen gün daha da artmaktadır (Aptekar, 1994). İstanbul, İzmir, Ankara, Diyarbakır, Gaziantep, Adana ve Bursa sokakta çalışan çocuk sayısının en fazla olduğu illerdir. Türkiye' de istihdam edilen çocuk sayısı önceki yıllarda 2 milyon 270 bin iken bu sayı 1999-2006 yılları arasında 890 bin düzeyine düşmüştür. Ancak 2006-2012 yılları arasında çocuk işçiliğindeki azalmanın durduğu ve sayının tekrar artmaya başladığı gözlenmiştir. 2012 yılında çocuk işçi sayısı 893 bin olarak rapor edilmiştir. Okula devam ederken çalışan çocukların sayısı ise önceki yıllarda 272 bin iken \%64 oranında artarak 445 bin düzeyine yükselmiştir. Diğer yandan, 2014 yılında çalışma esnasında hayatını kaybeden çocuk oranı \%3 iken, çalışan çocuklardan \%3.4'ünün yaralanma ve sakatlanma yaşadığı saptanmıştır (TUİK, 2012; İSİG, 2015).

Çocukların sokakta çalışması, dünya genelinde bir sorun olarak görülmekle birlikte bunun altında yatan pek çok neden bulunmaktadır. Özellikle ülkemizdeki çocukların sokakta çalışmasının başlıca nedenleri arasında kültürel yapı, göç, yoksulluk, ebeveynlerin işsizliği, aile bireylerinden birinin hastalığı, eğitimsizlik, parçalanmış aile yapısı, üvey anne baba, ihmal ve istismar bulunmaktadır (Clark, 2011; Güneş ve Kalayc1, 2004; Kızmaz ve Bilgin, 2010; Yıldırım, Ürkmez ve Koç, 2007;). Çocukların küçük yaştan itibaren çalışmaya başlaması, fiziksel ve ruhsal açıdan birçok olumsuzluk yaratırken, uzun vadede çocuğun sosyal gelişimi içinde bir risk oluşturabilmektedir. Bu çocuklar okul terki, sigara ve madde bağımlılığı, suça yönelme, aşağılanma, dışlanma, yalnızlık, şiddet, istismar, depresyon gibi tehlikelerle karşılaşabilmektedirler (Bilgin, 2012; Bilgin, 2008; Durualp, 2010; Ennew, 2003; Sütoluk, 2005). Bundan dolayı çocukların sokakta çalışması önemli sosyo-psikolojik sorunların ortaya çıkmasına zemin hazırlayabilmektedir (Fidan, 2004). Ebeveynlerin boşanması, evi terk etmesi, ebeveynlerden birinin ya da ikisinin ölümü gibi durumlar söz konusu olduğunda ise benzeri 
sorunların ortaya çıkma riski artmaktadır. Dünya çapında konuyla ilgili yapılmış araştırmalar ailenin ölüm, boşanma veya terk nedeniyle parçalandığ 1 durumlarda, çocuğun risk altında olduğunu göstermektedir (Emery, 2009). Ebeveynin herhangi bir nedenle yokluğu, çocuk ve gençlerin emniyet duygusundan yoksun kalmalarına, rol modellerini kaybetmelerine, dolayısıyla yaşadıkları problemlerin artmasına sebep olabilmektedir (Bayraktar, 1995). İstanbul Valiliği'nin 2005 yılında yapmış olduğu araştırmaya göre çocukların sokağa çıkma nedenlerinin başında \%20,7'lik oran ile aile ile uyumsuzluk yaşama gelmektedir (Coştu, 2007). SHÇEK'in 2010 yılında yayınladığı, rapora göre sokakta çalışan çocukların çoğunluğunun birçoğunun ailede şiddete maruz kaldığı ve aile içi ilişkilerinin zayıf olduğu belirtilmiştir.

Yalnızlık; üzüntü, öfke, kaygı ve kendini diğer bireylerden farklı hissetme duygularının eşlik ettiği istenmeyen bir deneyim olarak tanımlanmaktadır. Ebeveynlerden birinin ya da ikisinin yokluğu çocuklar üzerindeki yalnızlık hissine sebep olabilmektedir Bilinenin aksine yalnızlık duygusu çocuk ve ergenlerde ileri yetişkinliğe göre daha yaygın olarak görülmektedir (Alonzo, 1989). Mahon ve Yarcheski (1992), çocuk ve ergenlerde sosyal destek azaldıkça yalnızlık düzeyinin arttığını belirtmişlerdir. Benzeri şekilde Bullock'a (1993) göre sıcak, sevecen ve destekleyici ailelere sahip olan, çocukların yalnızlık düzeyleri daha düşüktür. Parçalanmış aileye sahip çocuklar ise yalnızlık konusunda diğer çocuklara göre daha dezavantajı bir gruptur. Konuyla ilgili yapılan çeşitli araştırmaların bulguları da parçalanmış aileye sahip çocukların yalnızlık düzeylerinin diğerlerinden daha yüksek olduğunu göstermiştir (Çivitçi, Çivitçi ve Fiyakalı, 2009; Garnefski ve Diekstra, 1997). Yalnızlık ile ilgili alan yazın incelendiğinde çocuklarda yalnızlık ile depresyonun ilişkili olduğunu gösteren çeşitli araştırma bulguları görülmektedir (Nangle, Erdley, Newman, Mason ve Carpenter, 2003; Lau, Chan ve Lau, 1999). Öztürk'e (2004) göre depresyon; bunaltılı ve üzüntülü bir duygu durumu olmakla birlikte aynı zamanda konuşmada ve fizyolojik işlevlerde yavaşlama, durgunlaşmanın eşlik ettiği isteksizlik, güçsüzlük ve değersizlik hislerini içinde barındıran bir durumdur. Parçalanmış aileye sahip çocuklarda yalnızlığın özellikle sokakta çalışmak zorunda olan çocuklarda zorlu yaşam koşullarıla birleştiğinden depresyon riskini güçlendiren bir faktör olduğu düşünülmektedir. Kerfoot ve diğerlerine (2007) göre sokaktaki çocukların \%74'ü depresyon yaşamaktadır. Bu konuda yapılan benzer çalışmalar da sokakta çalışan çocukların depresyon düzeylerinin çalışmayan çocuklardan daha yüksek olduğunu göstermiştir (Aydın, Çiftçi ve Karataş, 2015; Durualp, 2015; Erdoğdu, 2012; Woan, Lin ve Auerswald, 2013).

Bu bilgiler ışığında parçalanmış aile yapısı, yalnızlık ve depresyonun sokakta çalışan çocukları tehdit eden önemli birer risk faktörü olduğu ileri sürülebilir. Bu çocukların sosyal ve duygusal gelişimleri olumsuz etkilenmekte, bunların birer sonucu olarak da çocuklar yanlış akran gruplarına katılabilmekte hatta sokağa yönelerek evi terk edebilmektedirler (SHÇEK, 2010). Çocukluk döneminde sokakta çeşitli sömürü ve şiddete açı çocuklar ergenlik ve yetişkinlik dönemlerinde suç teşkil eden davranışlara yönelebilmektedirler (UNICEF, 2007). Sokakta çalışan ya da yaşayan çocuklara yönelik müdahale çalışmalarına bakıldığında son yıllarda önleyici hizmetlerin ön plana çıktığı görülmektedir. Çocukların karşı karşıya oldukları riskli durumların saptanmasına yönelik araştırmaların bu tür önleyici hizmetler için bir basamak oluşturacağ1 düşünülmektedir. Türkiye'de sokakta çalışan çocuklarda depresyonu inceleyen sınırlı sayıda çalışma olsa da (Aydın, Çiftçi ve Karataş, 2015; Durualp, 2015; Erdoğdu, 2012), depresyonu yalnızlık ve parçalanmış aile yapısı bağlamında ele alan bir çalışmaya ulaşılamamıştır. Bu nedenle, sokakta çalışmak zorunda kalan çocuklara yönelik bu tür 
çalışmaların hem var olan riskleri azaltmak hem de ileride oluşacak riskleri önleyebilmek açısından önemli olduğu düşünülmektedir.

Araştırmada İstanbul ilinde sokakta çalışan çocukların, ebeveynlerin sağ-ölü, öz-üvey ve evliboşanmış oluşuna göre yalnızlık ve depresyon düzeylerinin incelenmesi amaçlanmıştır. Bu amaç doğrultusunda oluşturulan denencelere aşağıda yer verilmiştir.

a. Sokakta çalışan çocukların yalnızlık ve depresyon düzeyleri ebeveynlerin sağ-ölü, özüvey ve evli-boşanmış oluşuna göre değişmektedir.

b. Sokakta çalışan çocuklarda yalnızlık depresyon için anlamlı bir yordayıcıdır.

\section{Yöntem}

\section{Araştırma Modeli}

Araştırmada, değişkenler arasındaki etkileşimin varlığını ve miktarını belirlemede kullanılan betimsel bir metod olan ilişkisel tarama modeli kullanılmıştır (Fraenkel ve Wallen, 1996).

\section{Çalışma Grubu}

Çalışma grubunu 2017-2018 eğitim öğretim yılında İstanbul'da ilköğretim ikinci kademde eğitim gören ve aynı zamanda sokakta çalışan, yaşları 10-14 arasında değişen 651 çocuk oluşturmaktadır. Araştırmada örnekleme alınan çocukların belirlenmesinde amaçlı örnekleme yöntemi kullanılmış, çalışan çocuk sayısının fazla olduğu benzer sosyoekonomik özelliklere sahip sekiz okuldan veri toplanmıştır.

\section{Veri Toplama Araçları}

Araştırmada, sokakta çalışan çocukların yalnızlık düzeylerini belirlemek amacıyla "UCLA Yalnızlık Ölçeği", depresyon düzeylerini belirleme amacıyla "Çocuklar İçin Depresyon Ölçeği" kullanılmıştır. Ebeveynlerin sağ-ölü, öz-üvey ve evli-boşanmış oluşunu belirlemek amacıyla araştırmacılar tarafından hazırlanan "Kişisel Bilgi Formu” kullanılmıştır.

\section{Çocuklar İçin Depresyon Ölçeği}

Ölçeğin orijinali Kovacs (1981) tarafından geliştirilmiş, Türkiye'deki geçerlilik ve güvenilirlik çalışması ise Öy (1991) tarafından yapılmıştır. 27 maddeden oluşan ölçekte çocuğun son iki haftasını değerlendirerek kendisine uygun bulacağı üç durum bulunmaktadır. Her durum çocukluk depresyonunun belirtilerine ilişkin ifadeler içermektedir. Seçilen durumlar 0, 1, 2 puan olacak şekilde değerlendirilmekte ve puanlar toplanarak depresyon puanı elde edilmektedir. Ölçeğin kesme puanı 19, ölçekten alınabilecek en yüksek puan 54'tür. Toplam puanın yüksek oluşu depresyon düzeyinin veya şiddetinin yüksekliğini ifade etmektedir. Öy (1991) tarafından yapılan uyarlama çalışmasında ölçeğin iç tutarlık katsayısı .86, dört hafta arayla yapılan test tekrar test güvenirliği .77 olarak bulunmuştur. Çocuklar İçin Depresyon 
Ölçeği puanlarının Çocukluk Depresyonu Derecelendirme Ölçeği puanlarıyla korelasyonu 0.61 olarak bulunmuştur (Öy, 1991).

\section{UCLA Yalnızlık Ölçeği}

Russel, Peplau ve Ferguson (1978) tarafından geliştirilen ‘UCLA Yalnızlık Ölçeği’nin Türkiye geçerlilik ve güvenirlik çalışması Demir (1989) tarafından yapılmıştır. Ölçeğin orijinal formunun güvenirlik çalışmasında iç tutarlılık katsayısı .96, test tekrar test güvenirliği .73 olarak bulunmuştur. Ölçeğin Türkiye formunun güvenirlik çalışmasında ise iç tutarlılık katsayıs1 .96, test tekrar test güvenirliği .94 olarak bulunmuştur (Demir, 1990). Bireyin genel yalnızlık düzeyini saptamak amacıyla geliştirilen UCLA Yalnızlık Ölçeği, 10'u düz, 10'u ters olmak üzere 20 maddeden oluşmaktadır. Bu ölçeğin her bir maddesinde sosyal ilişkilerle ilgili duygu veya düşünce içeren bir durum sunulmakta ve bireyin bu durumu ne sıklıkta yaşadığını belirtmesi istenmektedir. Olumlu ifadeleri içeren maddeler, hiç yaşamam: 4, nadiren yaşarım: 3, bazen yaşarım: 2, sık sık yaşarım: 1 şeklinde, olumsuz ifadeleri içeren maddeler ise bunun tam tersi olarak puanlanmaktadır. Tüm maddelerden alınan puanlar toplanarak toplam ölçek puanı elde edilmektedir. Ölçekten alınabilecek en yüksek puan 80, en düşük puan 20'dir. Ölçekten alınan yüksek puan, yalnızlığın daha yoğun yaşandığının göstergesi olarak kabul edilmektedir (Demir 1989).

\section{Verilerin Toplanması ve Analizi}

Araştırmanın verileri İstanbul'da sokakta çalışan ve çeşitli okullarda eğitimine devam eden çocuklardan elde edilmiştir. Verilerin analizinde, değişkenler arasında anlamlı bir ilişkinin olup olmadığını saptamak amacıyla Pearson Korelasyon Katsayısı Analizi, bağımsız gruplara ait ölçümlerin ortalamaları arasındaki farkın anlamlı olup olmadığını saptamak amacıyla Bağımsız Örneklemler İçin t-testi ve Tek Yönlü Varyans Analizi Tekniği kullanılmıştır. Ortalamalar arası farkın anlamlı olduğu durumlarda bu anlamlılığın hangi gruplardan kaynaklandığını saptama amacıyla LSD Testi kullanılmıştır. İki değişken arasındaki yordama gücünü saptamak için ise Basit Doğrusal Regresyon Analizi kullanılmıştır (Büyüköztürk, 2010).

\section{Bulgular}

Bu bölümde öncelikle sokakta çalışan çocukların aile yapısına ilişkin betimsel istatistiklere yer verilmiş, ardından istatistiksel analizlere ve analizler sonucunda elde edilen bulgulara yer verilmiştir.

Araştırmada yer alan çocukların aile yapısına ilişkin özelliklere bakıldığında; çocukların \%74.3'ünün annesinin sağ olduğu, \%25.7'sinin annesinin hayatta olmadığı, çocuklardan \%20.1'inin ise üvey anneye sahip olduğu saptanmıştır. Diğer yandan çocukların \%77.7'sinin babasının sağ olduğu, \%22.3'ünün babasının hayatta olmadığı, çocuklardan \%20.3'ünün ise üvey babaya sahip olduğu saptanmıştır. Ebeveynlerin medeni durumu açısından bakıldığında ise çocuklardan \%37.5'inin ebeveynlerinin evli ve \%20.9'unun boşanmış olduğu, çocuklardan 
\%41.6'sının ebeveynlerinden birinin ya da ikisinin hayatta olmadığı saptanmıştır. Çocukların sahip olduğu aile yapısına ilişkin betimsel istatistikler Tablo 1'de verilmiştir.

Tablo 1. Ebeveynlerin Sağ-Ölü, Öz-Üvey ve Evli-Boşanmış Oluşuna İlişkin Betimsel İstatistikler

\begin{tabular}{|c|c|c|c|}
\hline & & Frekans(N) & Yüzde (\%) \\
\hline \multirow[t]{4}{*}{ Anne Sağ/Ölü } & Sağ & 484 & 74.3 \\
\hline & Ölü & 167 & 25.7 \\
\hline & Toplam & 651 & 100 \\
\hline & Öz & 520 & 79.9 \\
\hline \multirow{2}{*}{ Anne /Öz-Üvey } & Üvey & 131 & 20.1 \\
\hline & Toplam & 651 & 100 \\
\hline \multirow{4}{*}{ Baba Sağ/Ölü } & Sağ & 506 & 77.7 \\
\hline & Ölü & 145 & 22.3 \\
\hline & Toplam & 651 & 100 \\
\hline & Öz & 519 & 79.7 \\
\hline \multirow[t]{3}{*}{ Baba/Öz-Üvey } & Üvey & 132 & 20.3 \\
\hline & Toplam & 651 & 100 \\
\hline & Evli & 244 & 37.5 \\
\hline \multirow{3}{*}{ Ebeveyn Medeni Durum } & Boşanmış & 136 & 20.9 \\
\hline & Ölü & 271 & 41.6 \\
\hline & Toplam & 651 & 100 \\
\hline
\end{tabular}

Verilerin analizine geçilmeden önce analizler için ön koşulların sağlanıp sağlanmadığı test edilmiştir. Yalnızlık ve depresyon düzeyleri için hesaplanan çarpıklık ve basıklık değerlerinin -1 ve 1 aralığında olduğu saptanmıştır. Bu değerler kabul edilebilir sinırlar içindedir ve verilere ilişkin normal dağılımın göstergesidir (Büyüköztürk, 2010). Araştırmada yer alan çocuklarda, ebeveynlerin sağ-ölü ve öz-üvey olma durumuna göre yalnızlık ve depresyon düzeylerinin değişip değişmediği t Testi ile incelenmiş ve sonuçlar Tablo 2'de verilmiştir. 
Tablo 2. Ebeveynlerin Sağ-Ölü ve Öz-Üvey Oluşuna Göre Sokakta Çalışan Çocukların Yalnızlık ve Depresyon Düzeylerine İlişkin t Testi Sonuçları

\begin{tabular}{|c|c|c|c|c|c|c|c|}
\hline & & $\mathbf{N}$ & $\bar{X}$ & $S$ & sd & $\mathbf{t}$ & $p$ \\
\hline \multirow[t]{2}{*}{ Yalnızlık } & Anne Sağ & 484 & 53.47 & 11.62 & 649 & -6.020 & $.000^{*}$ \\
\hline & Anne Ölü & 167 & 59.22 & 7.09 & & & \\
\hline \multirow[t]{2}{*}{ Depresyon } & Anne Sağ & 484 & 18.20 & 9.42 & 649 & -6.000 & $.000^{*}$ \\
\hline & Anne Ölü & 167 & 22.54 & 11.24 & & & \\
\hline \multirow[t]{2}{*}{ Yalnızlık } & Anne Öz & 520 & 54.14 & 11.33 & 649 & -3.768 & $.000^{*}$ \\
\hline & Anne Üvey & 131 & 58.31 & 8.50 & & & \\
\hline \multirow[t]{2}{*}{ Depresyon } & Anne Öz & 520 & 18.96 & 9.90 & 649 & -3.110 & $.002^{* *}$ \\
\hline & Anne Üvey & 131 & 19.20 & 10.93 & & & \\
\hline \multirow[t]{2}{*}{ Yalnızlık } & Baba Sağ & 506 & 53.98 & 11.19 & 649 & -4.277 & $.000^{*}$ \\
\hline & Baba Ölü & 145 & 58.32 & 9.23 & & & \\
\hline \multirow[t]{2}{*}{ Depresyon } & Baba Sağ & 506 & 18.71 & 9.79 & 649 & -4.089 & $.000^{*}$ \\
\hline & Baba Ölü & 145 & 22.59 & 10.95 & & & \\
\hline \multirow[t]{2}{*}{ Yalnızlık } & Baba Öz & 519 & 54.73 & 11.44 & 649 & -1.009 & .313 \\
\hline & Baba Üvey & 132 & 55.80 & 8.62 & & & \\
\hline \multirow[t]{2}{*}{ Depresyon } & Baba Öz & 519 & 19.13 & 9.95 & 649 & -2.230 & $.026^{* * *}$ \\
\hline & Baba Üvey & 132 & 21.33 & 10.92 & & & \\
\hline
\end{tabular}

${ }^{*} p<.001{ }^{* *} p<.01{ }^{* * *} p<.05$

Tablo 2' de yer alan veriler incelendiğinde sokakta çalışan çocukların yalnızlık ve depresyon düzeylerinin annenin hayatta olup olmaması ve öz-üvey olmasına göre anlamlı bir şekilde farklılaştığı saptanmıştır. Annesi hayatta olmayan çocukların yalnızlık ( $p=.000)$ ve depresyon $(p=.000)$ düzeylerinin annesi sağ olanlara göre anlamlı derecede yüksek olduğu, bununla birlikte üvey anneye sahip olan çocukların yalnızlık $(p=.000)$ ve depresyon $(p=.002)$ düzeylerinin de diğer gruba göre anlamlı derecede yüksek olduğu saptanmıştır. Baba özelliklerine ilişkin bulgular incelendiğinde ise babası hayatta olmayan çocukların yalnızlık $(p=.000)$ ve depresyon $(p=.000)$ düzeylerinin babası sağ olanlara göre anlamlı derecede yüksek 
olduğu saptanmıştır. Diğer yandan üvey babaya sahip olan çocukların depresyon düzeyi diğer gruba göre anlamlı derecede $(p=.026)$ yüksek iken yalnızlık düzeyinde gruplar arasında anlamlı bir fark $(p=.313)$ olmadığı saptanmıştır. Başka bir deyişle babası öz ve üvey olan çocukların yalnızlık düzeyleri arasında anlamlı bir farklılık bulunmamaktadır. Bu veriler 1şığında annesi hayatta olmayan çocukların ve üvey anneye sahip olan çocukların diğer çocuklara göre daha fazla depresyon yalnızlık ve hissi yaşadıkları ileri sürülebilir. Diğer yandan babası hayatta olmayan çocukların babası hayatta olan çocuklara göre daha yüksek depresyon ve yalnızlık düzeyine sahip olduğu söylenebilir. Bununla birlikte üvey babaya sahip olan çocukların depresyon düzeyleri diğer çocuklara göre daha yüksek iken yalnızlık düzeylerinin diğer çocuklardan farklılaşmadığ

Araştırmada yer alan çocuklarda, ebeveynlerin medeni durumuna göre yalnızlık ve depresyon düzeylerinin değişip değişmediği tek yönlü varyans analizi ile incelenmiş ve sonuçlar Tablo 3'te verilmiştir.

Tablo 3: Ebeveynlerin Medeni Durumuna Göre Sokakta Çalışan Çocukların Yalnızlık ve Depresyon Düzeylerine İlişkin Tek Yönlü Varyans Analizi Sonuçları

\begin{tabular}{ccccccc}
\hline & $\begin{array}{c}\text { Varyansın } \\
\text { Kaynağı }\end{array}$ & $\begin{array}{l}\text { Kareler } \\
\text { Toplamı }\end{array}$ & Sd & $\begin{array}{l}\text { Kareler } \\
\text { Ortalaması }\end{array}$ & F & $p$ \\
\hline Yalnızlık & Gruplar Arası & 8210.86 & 2 & 4105.43 & & \\
& Gruplar içi & 69428.25 & 648 & 107.14 & 38.318 & $.000^{*}$ \\
& Toplam & 77639.12 & 650 & & & \\
& Gruplar Arası & 6138.01 & 2 & 3069.01 & & \\
Depresyon & Gruplar içi & 61243.12 & 648 & 94.511 & 32.472 & $.000^{*}$ \\
& Toplam & 67381.14 & 650 & & & \\
\end{tabular}

${ }^{*} p<.001$

Tablo 3'te yer alan veriler incelendiğinde sokakta çalışan çocukların depresyon ve yalnızlık düzeylerinin ebeveynlerin medeni durumuna göre göre anlamlı bir şekilde farklılaştığ 1 saptanmıştır. Araştırmada yer alan çocukların, ebeveynlerin medeni durumuna göre yalnızlık ve depresyon düzeylerinde ortaya çıan farkın hangi gruplardan kaynaklandığı LSD testi ile incelenmiş ve sonuçlar Tablo 4'te verilmiştir. 
Tablo 4. Ebeveynlerin Medeni Durumuna Göre Sokakta Çalışan Çocukların Yalnızlık ve

\begin{tabular}{|c|c|c|c|c|c|}
\hline & & eveyn Durumu & Evli & Boşanmış & Ölü \\
\hline & 50.71 & Evli & - & $.000^{*}$ & $.000^{*}$ \\
\hline \multirow[t]{2}{*}{ Yalnızlık $(\bar{X})$} & 55.06 & Boşanmış & $.000^{*}$ & - & $.001^{* *}$ \\
\hline & 58.71 & Ölü & $.000^{*}$ & $.001^{* *}$ & - \\
\hline \multirow[t]{3}{*}{ Depresyon $(\bar{X})$} & 16.02 & Evli & - & $.002^{* *}$ & $.000^{*}$ \\
\hline & 19.29 & Boşanmış & $.002^{* *}$ & - & $.000^{*}$ \\
\hline & 22.92 & Ölü & $.000^{*}$ & $.000^{*}$ & - \\
\hline
\end{tabular}

Depresyon Düzeylerine İlişkin LSD Testi Sonuçları

${ }^{*} p<.001{ }^{* *} p<.01$

Tablo 4'te yer alan veriler incelendiğinde, sokakta çalışan çocukların yalnızlık ve depresyon düzeylerinin ebeveynlerin medeni durumuna göre farklılaştığı saptanmıştır. Buna göre, ebeveynleri evli olan çocukların yalnızlık düzeyleri ebeveynleri boşanmış $(p=.000)$ ve ölmüş $(p=.000)$ olanlara göre anlamlı derecede düşüktür. Diğer yandan ebeveynleri boşanmış olan çocukların yalnızlık düzeylerinin de ebeveynleri ölmüş olan çocuklardan anlamlı düzeyde ( $p=.001)$ düşük olduğu saptanmıştır. İlgili alan yazın incelendiğinde sosyal destek düzeyi düşük olan, parçalanmış aileye sahip olan ve tek ebeveyn ile yaşayan ergenlerin daha yoğun yalnızlık hissi yaşadıklarına ilişkin bulgular mevcuttur (Çivitçi, Çivitçi ve Fiyakalı, 2009; Garnefski ve Diekstra, 1997; Körler, 2011; Köse, 2009; Lee ve Goldstein, 2016; Mahon ve Yarcheski, 1992). Bu veriler ışığında ebeveynlerin boşanmasının ya da herhangi bir ebeveynin ölümünün, çocukların sosyal destek düzeyini azalttığı ve bu çocukların daha yoğun yalnızlık hissi yaşadığı ileri sürülebilir.

Depresyon düzeyi açısından incelendiğinde, ebeveynleri evli olan çocukların depresyon düzeylerinin ebeveynleri boşanmış $(p=.002)$ ve ölmüşs $(p=.000)$ olanlara göre anlamlı derecede düşük olduğu saptanmıştır. Diğer yandan ebeveynleri boşanmış olan çocukların depresyon düzeyleri de ebeveynleri ölmüş olan çocuklardan anlamlı düzeyde $(p=.000)$ düşüktür. Depresyonla ilgili alan yazın incelendiğinde ergenlerde parçalanmış aile yapısının ve sosyal destek yetersizliğinin depresyonu tetikleyici bir risk faktörü olarak tanımlandığ görülmektedir (Bifulco, Brown ve Harris, 1987; Elmacı, 2006; McLeod, 1991; Parker ve Roy 2001). Bu bulgular ışığında aile bütünlüğü bozulmuş olan çocukların gerek deneyimledikleri travmatik yaşantı (boşanma ya da ebeveyn kaybı) gerekse ihtiyaç duydukları sosyal destekten mahrum kalmaları sebebiyle depresyon düzeylerinin daha yüksek olduğu ileri sürülebilir.

Araştırmada yer alan çocuklarda yalnızlığın depresyon için anlamlı bir yordayıcı olup olmadığı basit doğrusal regresyon analizi ile incelenmiştir. Basit regresyon analizi iki değişken arasındaki ilişkinin, bağımsız değişkene dayalı olarak bağımlı değişkenin tahmin edilmesine yönelik bir regresyon eşitliği ile açıklanmak istenmesi durumunda kullanılmaktadır 
(Büyüköztürk, 2010). Regresyon analizine geçmeden önce bağımsız değişkenler arasındaki ilişki ve verilere ilişkin normallik, doğrusallık koşullarının sağlanıp sağlanmadığı incelenmiş̧tir. Depresyon ve yalnızlık değişkenleri arasındaki ilişki Pearson Momentler Çarpımı ile incelenmiş, iki değişken arasındaki korelasyon $\mathrm{r}=.11$ olarak bulunmuştur. Yalnızlık ve depresyon düzeyleri için hesaplanan çarpıklık ve basıklık değerlerinin -1 ve 1 aralığında olduğu saptanmıştır. Bu değerler kabul edilebilir sınırlar içindedir ve verilerin normal dağıldığının bir göstergesidir. Doğrusallık koşulu ise saçılma diyagramı ile incelenmiş ve değişkenler arasında doğrusallık sorunun olmadığı görülmüştür (Büyüköztürk, 2010; Leech, Barrett ve Morgan, 2008). Normallik ve doğrusallık koşulları karşılandığından regresyon analizi yapılmış ve sonuçlar Tablo 5 'te verilmiştir.

Tablo 5. Sokakta Çalışan Çocuklarda Depresyonun Yordanmasına İlişkin Regresyon Analizi Sonuçları

\begin{tabular}{llllll}
\hline Değişken & B & Standart Hata & $\beta$ & T & $p$ \\
\hline Sabit & 14.157 & 2.037 & - & 6.950 & .000 \\
Yalnızlık & .099 & .036 & .106 & 2.712 & $.007^{*}$ \\
\hline
\end{tabular}

${ }^{*} p<.01$

Tablo 5'te yer alan veriler incelendiğinde yalnızlı̆̆ın depresyon için anlamlı bir yordayıcı olduğu saptanmıştır ( $p=.007$ ). Regresyon analizi sonucunda $\mathrm{R}^{2}$ değeri .011 olarak bulunmuştur. Başka bir deyişle sokakta çalışan çocuklarda yalnızlığın, depresyona ilişkin varyansın \%11'ini açıkladığı görülmüştür. Bu veriler ışı̆̆ında sokakta çalışan çocuklara ilişkin depresyon düzeyinin yordanmasında \%11'lik kısmın yalnızlık değişkeni ile açılanabileceği ve yalnızlığın depresyonla ilişkili önemli bir risk faktörü olduğu ileri sürülebilir.

\section{Tartışma Yorum ve Öneriler}

Araştırmada elde edilen bulgular bir bütün halinde değerlendirildiğinde; annesi hayatta olmayan çocukların ve üvey anneye sahip olan çocukların depresyon ve yalnızlık düzeylerinin diğerlerinden daha yüksek olduğu saptanmıştır. Bununla birlikte babası hayatta olmayan çocukların ve üvey babaya sahip olan çocukların depresyon düzeylerinin diğerlerinden daha yüksek olduğu bulunmuştur. Benzer şekilde babası hayatta olmayan çocukların yalnızlık düzeylerinin diğerlerinden daha yüksek olduğu ancak yalnızlık düzeyinin babanın öz-üvey olmasına göre farklılaşmadığı saptanmıştır. Araştırmada ayrıca ebeveynleri evli olan çocukların depresyon ve yalnızlık düzeylerinin ebeveynleri boşanmış ve ölmüş olanlara göre anlamlı derecede düşük olduğu ve yalnızlığın depresyon için anlamlı bir yordayıcı olduğu bulgusu elde edilmiştir.

Araştırmada sokakta çalışan çocuklardan annesi hayatta olmayanların yalnızlık ve depresyon düzeylerinin annesi sağ olanlara göre anlamlı derecede yüksek olduğu saptanmıştır. Bununla birlikte babası hayatta olmayan çocukların yalnızlık ve depresyon düzeylerinin de babası sağ 
olanlara göre anlamlı derecede yüksek olduğu bulunmuştur. Elde edilen bulguların alan yazındaki diğer araştırma bulguları ile tutarlı olduğu görülmektedir. Murphy'nin (1987) yaptığı araştırmada, çocukluk döneminde yaşanan ebeveyn kaybının yalnızlık için önemli bir risk faktörü olduğu belirtilmiştir. Benzer araştırma bulguları da çocukluk döneminde yaşanan stres ve zorlu yaşam olaylarının yalnızlık ile yakından ilişkili olduğunu göstermiştir (Lee ve Goldstein, 2016; Rotenberg, MacDonald ve King, 2004; Yöyen, 2016). Çocukluk döneminde yaşanan ebeveyn kaybının çocuk için travmatik bir durum oluşturması kaçınılmazdır. Bu travmanın yarattığı stres ve hayal kırıklığının kişiler arası ilişkileri olumsuz etkileyebileceği düşünülmektedir. Kişilerarası ilişkilerde ortaya çıkan olumsuzlukların içe kapanma ve sosyal izolasyon yoluyla çocuklarda yalnızlığı tetiklediği ileri sürülebilir. Diğer yandan azalan aile desteği ve sosyal desteğin de ergenlerde yalnızlık ve depresyonu arttırdığı belirlenmiştir (Elmac1, 2006; Lee ve Goldstein, 2016; Mahon ve Yarcheski, 1992). Ebeveynlerden birinin kayb1 ile birlikte diğer ebeveynin de yas sürecine girmesiyle çocukların tamamen aile desteğinden yoksun kalabildikleri düşünülmektedir. Bu tür durumlarda çocukların gerek yalnızlık gerek depresyon için risk altında oldukları ileri sürülebilir. Depresyon ile ilgili alan yazında, çocukluk ve ergenlik döneminde yaşanan ebeveyn kaybının ergenlik dönemi ve yetişkin yaşamda depresyon için bir risk faktörü olduğu belirlenmiştir (Brent, Melhem, Donohoe ve Walker, 2009; Bifulco, Brown ve Harris, 1987; Kendler, Sheth, Gardner ve Prescott, 2002; McLeod, 1991). Araştırma bulgularına bakıldığında, ebeveynin kaybının yarattığı travma ve boşluk duygusunun bu çocuklarda yalnızlık duygusuna zemin hazırladığı düşünülebilir. Diğer yandan ortaya çıkan yalnızlık hissine sokakta çalışmanın getirdiği zorlu yaşam koşullarının eklenmesi ile bu grupta yer alan çocuklarda depresyonun daha yoğun yaşandığ ileri sürülebilir.

Araştırmada ayrıca üvey anneye sahip olan çocukların yalnızlık ve depresyon düzeylerinin diğer gruba göre anlamlı derecede yüksek olduğu saptanmıştır. Diğer yandan üvey babaya sahip olan çocukların depresyon düzeyi diğer gruba göre anlamlı derecede yüksek iken yalnızlık düzeyinde gruplar arasında anlamlı bir fark olmadığı saptanmıştır. Başka bir deyişle babası öz ve üvey olan çocukların yalnızlık düzeyleri arasında anlamlı bir farklılık bulunmamaktadır. Bullock'a (1993) göre sıcak ve sevecen ailelere sahip olan ve aileleri tarafından desteklenen çocukların yalnızlık düzeyleri diğer çocuklara göre daha düşüktür. Benzer araştırma bulguları da azalan sosyal desteğin ergenlerde yalnızlık duygusunun artmasında etkili olduğunu göstermiştir (Bifulco, Brown ve Harris, 1987; Elmac1, 2006; Lee ve Goldstein, 2016; Mahon ve Yarcheski, 1992; McLeod, 1991; Parker ve Roy 2001). Bu açıdan bakıldığında üvey annenin çocuklarda sosyal destek ve aile desteği ihtiyacını karşılamakta yeterli olmadığı ve bunun yalnızlık ve depresyonu tetiklediği ileri sürülebilir. Diğer yandan üvey babaya sahip çocuklarda depresyon düzeyi diğer çocuklardan yüksek iken yalnızlık düzeyinin diğer gruptan farklılaşmaması düşündürücüdür. Bu durumun çocuğun anne ve babasıyla kurduğu ilişki tarzının birbirinden farklı olmasıyla açıklanabileceği düşünülmektedir. Anne ile ilişkinin temeli bebeklik yıllarından itibaren kurulan yakın duygusal bağ iken babayla kurulan ilişkide model alma ve bazı rollerin öğrenilmesi ön plandadır (Fine ve Kurdek, 1992). Bu nedenle üvey babaya sahip çocuklarda yakın duygusal ilişki ihtiyacının ve buna bağlı olarak yalnızlık düzeylerinin diğerlerinden farklılaşmadığ düşünülebilir. Benzeri araştırma bulguları, üvey babaya sahip ergenlerin üvey anneye sahip ergenlere göre yeni aile yapısına daha kolay uyum sağladıklarını, benlik saygılarının daha yüksek olduğunu ve daha az sosyal problemler yaşadıklarını göstermiştir (Clingempeel ve 
Segal, 1986; Downey, 1995; Fine ve Kurdek, 1992). Bu açıdan değerlendirildiğinde üvey babanın aileye katılmasıyla değişen aile yapısına uyum sağlayan bu çocukların yalnızlıkla daha kolay baş edebilecekleri düşünülebilir. Santrock, Warshak, Lindbergh ve Meadows'ın (1982) üvey babaya sahip çocuklar üzerinde yaptıkları araştırmada ise erkek çocukların kız çocuklara göre üvey babaya daha kolay uyum sağladıkları ve üvey babaya sahip çocukların sadece annesiyle yaşayan çocuklara göre daha olumlu davranışlar sergiledikleri saptanmıştır. Buradan hareketle erkek çocukların üvey babayı rol model olarak gördükleri ve kız çocuklara göre üvey babayla daha kolay ilişki kurdukları ileri sürülebilir. Araştırmanın örnekleminin çoğunluğunun erkek çocuklardan oluşması nedeniyle elde edilen bulguların bu çerçevede yorumlanmasının faydalı olacağı düşünülmektedir. Depresyon açısından bakıldığında ise üvey babaya sahip çocuklarda değişen aile yapısı nedeniyle çocuğun ekonomik sorumluluklarının artabildiği, bu durumun çocuğu karamsarlığa iterek gelecek beklentilerini azalttığı ve depresyona zemin hazırladığı düşünülebilir.

Araştırmada, sokakta çalışan çocukların yalnızlık ve depresyon düzeylerinin ebeveynlerin medeni durumuna göre farklılaştığı saptanmıştır. Buna göre, ebeveynleri evli olan çocukların yalnızlık düzeyleri ebeveynleri boşanmış ve ölmüş olanlara göre anlamlı derecede düşüktür. Diğer yandan ebeveynleri boşanmış olan çocukların yalnızlık düzeylerinin de ebeveynleri ölmüş olan çocuklardan düşük olduğu saptanmıştır. Depresyon düzeyi açısından da araştırma verileri incelendiğinde, ebeveynleri evli olan çocukların depresyon düzeylerinin ebeveynleri boşanmış ve ölmüş olanlara göre daha düşük olduğu; ebeveynleri boşanmış olan çocukların depresyon düzeylerinin de ebeveynleri ölmüş olan çocuklardan daha düşük olduğu görülmüştür. Elde edilen bulguların alan yazındaki diğer araştırma bulguları ile tutarlı olduğu görülmektedir. Parçalanmış aileye sahip olan ve tek ebeveyn ile yaşayan ergenlerin yalnızlık düzeylerinin diğerlerinden daha yüksek olduğu belirtilmiştir (Çivitçi, Çivitçi ve Fiyakalı, 2009; Garnefski ve Diekstra, 1997; Körler, 2011; Köse, 2009). Bununla birlikte yalnızlı̆̆ın çocukluk yıllarında kişiler arası ilişkilerinde yaşanan olumsuz yaşantılar ile ilişkili olduğu kabul edilmektedir (Rotenberg, MacDonald ve King, 2004). Bu dönemde yaşanan ebeveyn kaybının yada ayrılığının çocuklar için zorlu ve travmatik bir olay olduğu düşünüldüğünde, yalnızlık için önemli bir risk faktörü olduğu ileri sürülebilir. Bullock'a (1993) göre göre sıcak ve sevecen ailelere sahip olan, aileleri tarafından desteklenen çocukların yalnızlık düzeyleri daha düşüktür. Benzer araştırma bulguları da sosyal destek azaldıkça ergenlerde yalnızlık düzeyinin arttığını göstermiştir (Lee ve Goldstein, 2016; Mahon ve Yarcheski, 1992). Bu bilgiler ışı̆̆ında ebeveyn kaybı yaşayan ya da ebeveynleri ayrılmış olan çocukların yeterince sıcak ve yakın ilişkiler geliştirmekte zorlandıkları, ihtiyaçları olan sosyal destekten yoksun kaldıkları, bunun sonucunda yalnızlık düzeylerinin daha yüksek olduğu düşünülebilir. Depresyonla ilgili alan yazın incelendiğinde ergenlerde parçalanmış aile yapısının ve sosyal destek yetersizliğinin ergenlik dönemi ve yetişkinlikte depresyonu tetikleyici bir risk faktörü olarak tanımlandığ1 görülmüştür (Bifulco, Brown ve Harris, 1987; Elmacı, 2006; McLeod, 1991; Parker ve Roy 2001). Bu açıdan bakıldığında ebeveynin kaybı ya da ebeveynlerin boşanmasıyla ortaya çıkan; değişen aile yapısı, sevilen kişinin kaybı, sosyal desteğin azalması gibi faktörlerin depresyonun gelişmesinde rol oynadığı söylenebilir. Ulusoy, Demir ve Baran'ın (2005) yaptığı araştırmada parçalanmış aileye sahip ergenlerde geleceğe ilişkin beklentilerin daha az olduğu, intihar eğilimin, psikotik ve depresif belirtilerin daha yüksek olduğu saptanmıştır. Bu dönemde zorlu yaşam olaylarıyla baş etmekte zorlanan bu çocukların, değişen aile yapısına 
sokağın içerisinde barındırdığı tehlikeler ile sokakta çalışmanın getirdiği sorumlulukların da eklenmesiyle depresyon açısından daha yüksek risk altında olacakları ileri sürülebilir.

Araştırmada ayrıca yalnızlığın depresyon için anlamlı bir yordayıcı olduğu saptanmıştır. Başka bir deyişle sokakta çalışan çocuklarda yalnızlık, depresyona ilişkin varyansın \%11'ini açıklamaktadır. Alan yazındaki benzer araştırma bulguları da bu bulguyu destekler niteliktedir (Nangle, Erdley, Newman, Mason ve Carpenter, 2003; Panicker ve Sachdev, 2014). $\mathrm{Bu}$ açıdan bakıldığında yalnızlık duygusunun çocuk ve ergenlerde depresyonun ortaya çıkmasında etkili bir risk faktörü olduğu söylenebilir. Alan yazında sosyal destek ve aidiyet duygusunun depresyon ile yakından ilişkili olduğu belirtilmiştir (Bifulco, Brown ve Harris, 1987; Elmacı, 2006; Hagerty ve Williams, 1999; McLeod, 1991; Parker ve Roy 2001). Çocuğun depresyon döneminde sosyal desteğe gereksinimi vardır. Bu dönemde yeterli destek göremeyen bireyler karşılaştıkları zorluklarla yalnız mücadele etmek zorunda kalabilmektedirler. Bu bilgiler ışığında azalan sosyal destek ve aidiyet duygusunun çocuk ve ergenlerde yalnızlık hissini tetiklediği ve buna bağlı olarak depresyon düzeyinin yükseldiği ileri sürülebilir.

Araştırmadan elde edilen bulgular ve bulgulara dayanılarak varılan sonuçlar doğrultusunda birtakım öneriler geliştirilmiştir. Çocukların sokaktan uzaklaştırılması toplumsal bir sorun olmakla birlikte tüm ülkeler için ulaşılması gereken uzun vadeli bir hedeftir. Bu nedenle çocukların sokakta çalışma koşulları, sokakta çalışmanın riskleri ve etkileri göz önüne alınarak, buna son verecek önlemlere gereksinim duyulmaktadır. Diğer yandan bu çocukların evi terk ederek tamamen sokağa yönelmelerinin ve riskli davranışlar geliştirmelerinin önüne geçmek için yaşam koşullarının incelenip iyileştirilmesi önemlidir. Sokakta çalışan çocuklara sağlık ve eğitim kurumlarında rehberlik ve danışmanlık hizmeti verilmesinin ruh sağlığının korunması ve riskli davranışların önlenmesi açısından gerekli olduğu düşünülmektedir. Parçalanmış aileye sahip çocukların yalnızlık, depresyon ve sokağa yönelme konusunda daha yüksek risk altında oldukları düşünülmektedir. Bu nedenle özellikle bu grupta yer alan çocuklara yönelik koruyucu ve iyileştirici müdahalelere ağırlık verilmelidir. Aile ve arkadaş ilişkilerindeki değişiklikler değerlendirilmeli, destekleyici programlar oluşturulmalı, bu konuda aileler, öğretmenler, okul rehberlik uzmanları, okul yönetimleri ve sosyal hizmet birimleri işbirliği içerisinde hareket etmelidir.

Araştırmadan elde edilen sonuçların değerlendirilmesinde araştırmanın sınırlılıklarının da göz önüne alınmasının önemli olduğu düşünülmektedir. Bu araştırmada yer alan çocukların hepsi eğitim ve öğretimlerine devam eden çocuklardır. Bu nedenle araştırma bulgularının okula devam etmeyen çocukların bulgularıyla karşılaştırılmasına ihtiyaç duyulabilir. Diğer yandan sokakta çalışmanın çocuklar üzerindeki etkisini daha detaylı inceleyebilmek için araştırma bulgularının aynı okullarda eğitim gören benzer demografik özelliklere sahip ancak sokakta çalışmayan çocukların bulgularıyla karşılaştırılması katkı sağlayabilir. 


\section{Sokakta Çalışan Çocukların Yalnızlık ve Depresyon Düzeylerinin Ebeveyn Durumları Açısından İncelenmesi: İstanbul Örneği}

\section{Kaynakça}

Alacahan, O. (2010). Çocuğunu sokakta çalıştıran ailelerin sosyoekonomik profili, tutum ve beklentileri. Sosyal Siyaset Konferansları, 59, 133-47.

Alonzo, A.A. (1989). Loneliness, theory, research and applications. Contemporary Sociology, 18(3), 437-438.

Aptekar L. (1994). Street children in the developing world: A reiview of their condition. CrossCultural Research, 281, 195-224.

Aydın, D., Çiftçi, E. K. ve Karataş, H. (2015). Sokakta çalışan çocukların depresyon durumlarının belirlenmesi. The Journal of Pediatric Research, 2(1), 31-36.

Bayraktar, M. F. (1995). Ailenin eğitim görevi. Din Eğitimi Araştırmaları Dergisi, 2, 122-123.

Bifulco, A. T., Brown, G. W. ve Harris, T. O. (1987). Childhood loss of parent, lack of adequate parental care and adult depression: a replication. Journal of affective disorders, 12(2), 115-128.

Bilgin, R. (2008). Sokakta çalışan çocuklar sorununa sosyolojik bir yaklaşım: Diyarbakır örneği. Yayımlanmamış Doktora Tezi, Fırat Üniversitesi, Sosyal Bilimler Enstitüsü.

Bilgin, R. (2012). Sokakta çalışan çocukları bekleyen risk ve tehlikeler: Diyarbakır örneği. Uluslararası Yönetim İktisat ve İşletme Dergisi, 8(15), 79-96.

Brent, D., Melhem, N., Donohoe, M. B. ve Walker, M. (2009). The incidence and course of depression in bereaved youth 21 months after the loss of a parent to suicide, accident, or sudden natural death. American Journal of Psychiatry, 166(7), 786-794.

Bullock, J. R. (1993). Children's loneliness and their relationships with family and peers. Family Relations, 46-49.

Büyüköztürk, Ş. (2010). Sosyal bilimler için veri analizi el kitabı (21.Baskı), Ankara: Pegem A Akademi.

Clark, R. (2011). Child labor in the world polity: decline and persistence, 1980-2000. Social Forces, 89(3), 1033-1055.

Clingempeel, W. G. ve Segal, S. (1986). Stepparent-stepchild relationships and the psychological adjustment of children in stepmother and stepfather families. Child Development, 57(2), 474484 .

Coştu, K. (2007). Sokak çocuklarının sosyo-kültürel yapısı (İstanbul örneği). Yayımlanmamış Yüksek Lisans Tezi, Marmara Üniversitesi, Sosyal Bilimler Enstitüsü.

Çivitci, N., Çivitci, A. ve Fiyakalı, C. (2009). Anne-babası boşanmış ve boşanmamış olan ergenlerde yalnızlık ve yaşam doyumu. Kuram ve Uygulamada Ĕ̆itim Bilimleri, 9(2), 493-525.

Demir, A. (1989). UCLA yalnızlık ölçeği'nin geçerlik ve güvenirliği. Psikoloji Dergisi, 7(8), 14-18.

Demir, A. (1990). Üniversite öğrencilerinin yalnızlık düzeylerini etkileyen bazı etmenler. Yayımlanmamış Doktora Tezi, Hacettepe Üniversitesi Sosyal Bilimler Enstitüsü.

Downey, D. B. (1995). Understanding academic achievement among children instephouseholds: The role of parental resources, sex of stepparent, and sex of child. Social Forces, 73(3), 875-894. 
Durualp E. (2007). Sokakta çalışan çocukların genel durumlarının incelenmesi: Çankırı il örneği. Yayımlanmamış Doktora Tezi, Ankara Üniversitesi, Fen Bilimleri Enstitüsü.

Durualp E, Karadut T, Kul G, Özen E, Gül D. (2010). Sokakta çalışan çocuklarda depresif belirtiler. Anadolu Psikiyatri Dergisi, 11, 161-168.

Durualp, E. ve Çiçekoğlu, P. (2013). Yetiştirme yurdunda kalan ergenlerin yalnızlık düzeylerinin internet bağımlılığı ve çeşitli değişkenler açısından incelenmesi. Dokuz Eylül Üniversitesi Sosyal Bilimler Enstitüsü Dergisi, 15(1), 29-46.

Elmacı, F. (2006). Parçalanmış ve bütünlügüüü koruyan aileye sahip ergenlerin depresyon ve uyum düzeylerinde sosyal desteğin rolü. Kuram ve Uygulamada Ĕ̆itim Bilimleri, 6(2), 403-431.

Emery, C. R. (2009). “Stay for the Children? Husband violence, marital stability, and children's behavior problems". Journal of Marriage and Family, 71,905-916.

Erdoğdu, M. Y. (2012). Sokakta çalışan çocukların depresif belirti düzeylerinin taranması: Karşılaştırılmalı çalışma. Selçuk Üniversitesi Sosyal Bilimler Enstitüsü Dergisi, (28), 77-87.

Erkan, R. ve Erdoğdu, M. Y. (2006) Göç ve çocuk suçluluğu. Aile ve Toplum Eğitim Kültür ve Araştırma Dergisi, 9, 79-89.

Ennew, J. (2003). Sokak çocukları ve çalışan çocuklar, Planlama için bir rehber. UNICEF Türkiye Temsilciliği, Ankara.

Fidan, F. (2004). Çalışan çocuk olgusuna sosyo-psikolojik bakış, sanayide çalışan çocuklar örneği. Trakya Üniversitesi Sosyal Bilimler Dergisi, 4(1), 30-49.

Fine, M. A. ve Kurdek, L. A. (1992). The adjustment of adolescents in stepfather and stepmother families. Journal of Marriage and the Family, 725-736.

Fraenkel, J. ve Wallen, N. (1996). How to design and evaluate research in evaluation. New York: McGraw-Hill.

Garnefski, N. ve Diekstra, R. F. (1997). Adolescents from one parent, stepparent and intact families: emotional problems and suicide attempts. Journal of adolescence, 20(2), 201-208.

Güneş, S. ve Kalaycl, A. R. (2004). Sokakta yaşayan/çalışan çocuklar: tespitler ve çözüm önerileri, Başbakanlık Aile ve Sosyal Araştırmalar Genel Müdürlüğü, http://www.aile.gov.tr/, Erişim (10.07.2017).

İSİG (2015). 2014 yılı iş cinayetleri raporu, İstanbul işçi sağlığı ve iş güvenliği meclisi, www.guvenlicalisma.org.tr, Erişim (02.05.2017).

Hagerty, B. M. ve Williams, A. (1999). The effects of sense of belonging, social support, conflict, and loneliness on depression. Nursing research, 48(4), 215-219.

Karabulut, Ö. (2000). Ekonomik istismar, çocukların çalıştırılması, çalışan çocukların sorunları ve çözüm yolları. İçinde M. R. Şirin (Ed.). 1. İstanbul Çocuk Kurultayı Bildiriler Kitabı. İstanbul.

Kendler, K. S., Sheth, K., Gardner, C. O. ve Prescott, C. A. (2002). Childhood parental loss and risk for first-onset of major depression and alcohol dependence: the time-decay of risk and sex differences. Psychological medicine, 32(7), 1187-1194. 


\section{Sokakta Çalışan Çocukların Yalnızlık ve Depresyon Düzeylerinin Ebeveyn Durumları Açısından İncelenmesi: İstanbul Örneği}

Kerfoot, M., Koshyl, V., Roganov, O., Mikhailichenko, K., Gorbova, I. ve Pottage, D. (2007). The health and well-being of neglected, abused and exploited children: The Kyiv Street Children Project. Child abuse \& neglect, 31(1), 27-37.

Kizmaz, Z. ve Bilgin, R. (2010). Sokakta çalışan/yaşayan çocuklar ve suç: Diyarbakır örneği. Elektronik Sosyal Bilimler Dergisi, 9(32), 269-311.

Kovacs, M. (1981). Rating scales to assess depression in school-aged children. Acta Paedopsychiatrica: International Journal of Child \& Adolescent Psychiatry, 46(5-6), 305-315.

Körler, Y. (2011). İlköğretim ikinci kademe öğrencilerinin çeşitli değişkenler açısından yalnızlık düzeyleri ve yalnızlık ile sosyal duygusal öğrenme becerileri arasındaki ilişkiler. Yayımlanmamış Yüksek Lisans Tezi, Anadolu Üniversitesi, Eğitim Bilimleri Enstitüsü.

Köse, E. (2009). Yurtta kalan ve ailesiyle birlikte yaşayan lise öğrencilerinin yalnızlık ve sosyal destek düzeylerinin incelenmesi. Yayımlanmamış Yüksek Lisans Tezi, Dokuz Eylül Üniversitesi, Eğitim Bilimleri Enstitüsü.

Kulaksızoğlu, A. (2006). Ergenlik psikolojisi, 8. Baskı, İstanbul: Remzi Kitabevi.

Lee, C. Y. S. ve Goldstein, S. E. (2016). Loneliness, stress, and social support in young adulthood: Does the source of support matter? Journal of youth and adolescence, 45(3), 568-580.

Lau, S., Chan, D. W. ve Lau, P. S. (1999). Facets of loneliness and depression among Chinese children and adolescents. The Journal of Social Psychology, 139(6), 713-729.

Mahon, N. E. ve Yarcheski, A. (1992). Alternate explanations of loneliness in adolescents: a replication and extension study. Nursing Research, 41(3), 151-156.

McLeod, J. D. (1991). Childhood parental loss and adult depression. Journal of Health and Social Behavior, 32(3), 205-220.

Murphy, P. A. (1987). Parental death in childhood and loneliness in young adults. OMEGAJournal of Death and Dying, 17(3), 219-228.

Müreddisoğlu, S. (2009). Sokak çocuklarının psikososyal sorunları ve müdahale çalışmaları. İçinde Çocuk Şiddeti ve Çalıştayı El Kitabı, 288-295.

Nangle, D. W., Erdley, C. A., Newman, J. E., Mason, C. A. ve Carpenter, E. M. (2003). Popularity, friendship quantity, and friendship quality: Interactive influences on children's loneliness and depression. Journal of Clinical Child and Adolescent Psychology, 32(4), 546-555.

Öy, B. (1991). Çocuklar için depresyon ölçeği: Geçerlilik ve güvenlik çalışması. Türk Psikiyatri Dergisi, 2, 132-136.

Panicker, J. ve Sachdev, R. (2014). Relations among loneliness, depression, anxiety, stress and problematic internet use. International Journal of Research in Applied, Natural and Social Sciences, 2(9), 1-10.

Parker, G. ve Roy, K. (2001). Adolescent depression: a review. Australian \& New Zealand Journal of Psychiatry, 35(5), 572-580.

Rotenberg, K. J., MacDonald, K. J. ve King, E. V. (2004). The relationship between loneliness and interpersonal trust during middle childhood. Journal of Genetic Psychology, 165, 233-249. 
Russell, D., Peplau, L. A. ve Ferguson, M. L. (1978). Developing a measure of loneliness. Journal of personality assessment, 42(3), 290-294.

Santrock, J. W., Warshak, R., Lindbergh, C. ve Meadows, L. (1982). Children's and parents' observed social behavior in stepfather families. Child Development, 472-480.

SHÇEK, (2010). Sokakta yaşayan ve/ veya çalıştırılan çocuklara yönelik hizmet modelinin ve il eylem planlarının değerlendirilmesi raporu. http://www.unicef.org.tr, Erişim (02.07.2017).

Sütoluk, Z., Nazlıcan, E., Azizoğlu, A. ve Akbaba, M. (2005). Yüreğir çıraklık eğitim merkezi öğrencilerinde depresyon sıklığ1 ve nedenleri. Türk Tabipler Birliği Mesleki Sağlık ve Güvenlik Dergisi, 23, 24-26.

Uluğtekin, S. (1997). Sokak çocukları. Eğitimcilerin eğitim programı, Bizim Büro Basımevi, İstanbul.

Ulusoy, D., Demir, N. Ö. ve Baran, A. G. (2005). Parçalanmış aile ve gençlerde sapmış davranışlar: lise son sınıf gençliği örneği. Edebiyat Fakültesi Dergisi, 22(2), 61-66.

TUIK, (2012). Çocuk işgücü istatistikleri 1994, 1999, 2006, 2012, www.tuik.gov.tr, Erişim (10.09.2017).

Tuncel, M. K. (2003). Türkiye ve Almanya'da sokak çocuklarına uygulanan eğitim programlarının karşılaştırılması ve bir model önerisi. Yayımlanmamış Doktora Tezi, Abant İzzet Baysal Üniversitesi, Sosyal Bilimler Enstitüsü.

UNICEF, 2007. The state of the world's children 2007. http://www.unicef.org, Erişim (02.07.2017).

Yıldırım, İ. E., Ürkmez, E. ve Koç, T. (2007). İstanbul'da kapkaç sorunu ve toplum üzerindeki etkileri. Marmara Üniversitesi İ̈BF Dergisi, 23(2), 371-388.

Yöyen, E. G. (2016). Childhood trauma and self-respect as a predictor of loneliness. Journal of Current Researches on Social Sciences, 6(2), 65-78. 